\title{
Use of Range Shrubs to Meet Nutrient Requirements of Sheep Grazing on Crested Wheatgrass during Fall and Early Winter
}

\author{
ROBERT OTSYINA, C.M. MCKELL, AND GORDON VAN EPPS
}

\begin{abstract}
This study considered the feasibility of supplementing crested wheatgrass (Agropyron cristatum Fisch.) forage with some common rangeland shrubs. The necessary proportions of shrub and grass in the diet to meet protein and energy requirements were calculated for gestating sheep during the late fall and early winter grazing season. Shrubs studied included fourwing saltbush Atriplex canescens Pursh. Nutt.), winterfat (Ceratoides lanata (Pursh Howell), rubber rabbitbrush (Chrysothamnus nauseosus ssp. albicaulis, (Nutt) Rydb.), and big sagebrush (Artemisia tridentata ssp. vaseyana Nutt.). The shrubs were consistently higher in both total and digestible protein than crested wheatgrass over the period of study. Fourwing saltbush and winterfat with 8.24 and $6.31 \%$ digestible protein, respectively, were found to be the most promising shrubs to be used to supplement the low protein content of crested wheatgrass for late fall grazing. To meet dietary requirements for gestating sheep would require a minimum of 56 to $69 \%$ of fourwing saltbush and winterfat respectively, in the diet. Sagebrush and rabbitbrush were lower in digestible protein content, 4.04 and $4.43 \%$, respectively, and therefore could not be used alone with crested wheatgrass.
\end{abstract}

The widespread adaptability and extensive use of crested wheatgrass (Agropyron desertorum Fisch) and Fairway crested wheatgrass (Agropyron cristatum (L) Goertn) indicate their importance to the range livestock industry. Bleak and Plummer (1954) estimated that crested wheatgrass had been seeded on 404,858 hectares ( 1 million acres) in the Intermountain West. These monospecific seedings of crested wheatgrass have long been used on arid intermountain ranges to provide improved grazing during the spring and early summer with the possibility of some grazing in the fall (Frischknecht 1968). Some of the foothill ranges are also used for overwintering sheep and cattle with or without supplementation (Kearl et al 1971).

Following the onset of plant maturity these pure stands of crested wheatgrass are low or deficient in protein, carotene, and phosphorus and are insufficient to meet gestation requirements for sheep and cattle (Cook 1972, Rauzi 1975). At the same time, however, these grasses have a high energy value. In contrast, some common salt desert shrubs are high in protein, carotene, and phosphorus but are low in energy (Cook 1971). Limited research has thus suggested that mature grass forage plus palatable shrubs will provide an adequate and balanced diet, and improve the performance of sheep during the late fall and early winter periods (Cook and Harris 1968, Chatterton et al. 1971, Van Epps et al. 1971).

The objectives of this study were first to determine the nutrient content of selected shrubs and crested wheatgrass in the late fall and early winter (September to December) and to determine their nutrient deficiencies, especially protein for grazing sheep; second

The senior author is with the Institute for Land Rehabilitation, UMC-52 Utah State University, Logan, Utah 84322. to determine individual plant productivities and the proportions of browse and crested wheatgrass that best meet the minimum nutrient requirements of sheep for gestation during the fall and early winter months with particular reference to protein and energy.

\section{Methods}

All plants sampled in this study, except big sagebrush were at the Nephi Field Station. The Nephi Field Station is situated in central Utah about $12 \mathrm{~km}$ south of Nephi. The climate in the area of the station is characterized by cold winters and relatively warm summers. Normal precipitation is in the form of snow in the winter and limited rainfall in the spring and summer. The long-term average precipitation is $31.25 \mathrm{~cm}$. Soil at the station is classified as Nephi silt loam and is deep and well drained.

Big sagebrush (Artemisia tridentata ssp. vaseyana Nutt. samples were taken from a native foothill range about $2 \mathrm{~km}$ east of Brigham City, Utah, on Highway 89-91 because plantings of the subspecies were not available at the Nephi Field Station. Average annual precipitation ranges from $30.5 \mathrm{~cm}$ to $40.6 \mathrm{~cm}$ and occurs mostly as snow in the winter. The vegetation of the area is predominatly big sagebrush and bluebunch wheatgrass (Agropyron spicatum).

Shrub plants included in this study were rubber rabbitbrush (Chrysothamnus nauseosus ssp. albicaulis (Nutt) Rydb), winterfat (Ceratoides lanata (Pursh) Howell), fourwing saltbush (Atriplex canescens (Pursh Nutt.), and big sagebrush.

Fifteen plants in each species were randomly selected from previously established plots at the Nephi field station and from a native stand at the Brigham City site. Each plant was divided into 4 approximately equal portions by tying a brightly colored string inside the crown at right angles to enable samples to be taken on the same plant at each harvest period. Current annual twig growth was clipped monthly using one quarter $(1 / 4)$ of each plant from September to December. Two other plants not previously clipped were retained as controls to determine the effects, if any, of clipping on the protein content in subsequent months.

Crested wheatgrass samples were obtained from a mono culture pasture using a meter square quadrat. All samples were dried, weighed, and analyzed for crude protein content by the Kjeldahl method (Harris 1970). Protein digestibility coefficients appropriate for sheep and metabolizable energy values for the various plant species were obtained from the literature (Cook and Harris 1968). These coefficients were used to calculate sheep diets from values collected in this study. Digestibility coefficients could not be determined within the scope of the present study. Analysis of variance (Steel and Torrie 1960) was used to determine the existence of differences in nutrient content with time. Results were considered significant at $\alpha=0.05$ unless otherwise stated.

Provisional diets were calculated using shrubs a basic protein supplement for balancing the nutritional requirements of gestating ewes during the winter period. Minimum requirements were based on the National Research Council (1975) recommendations for sheep. 


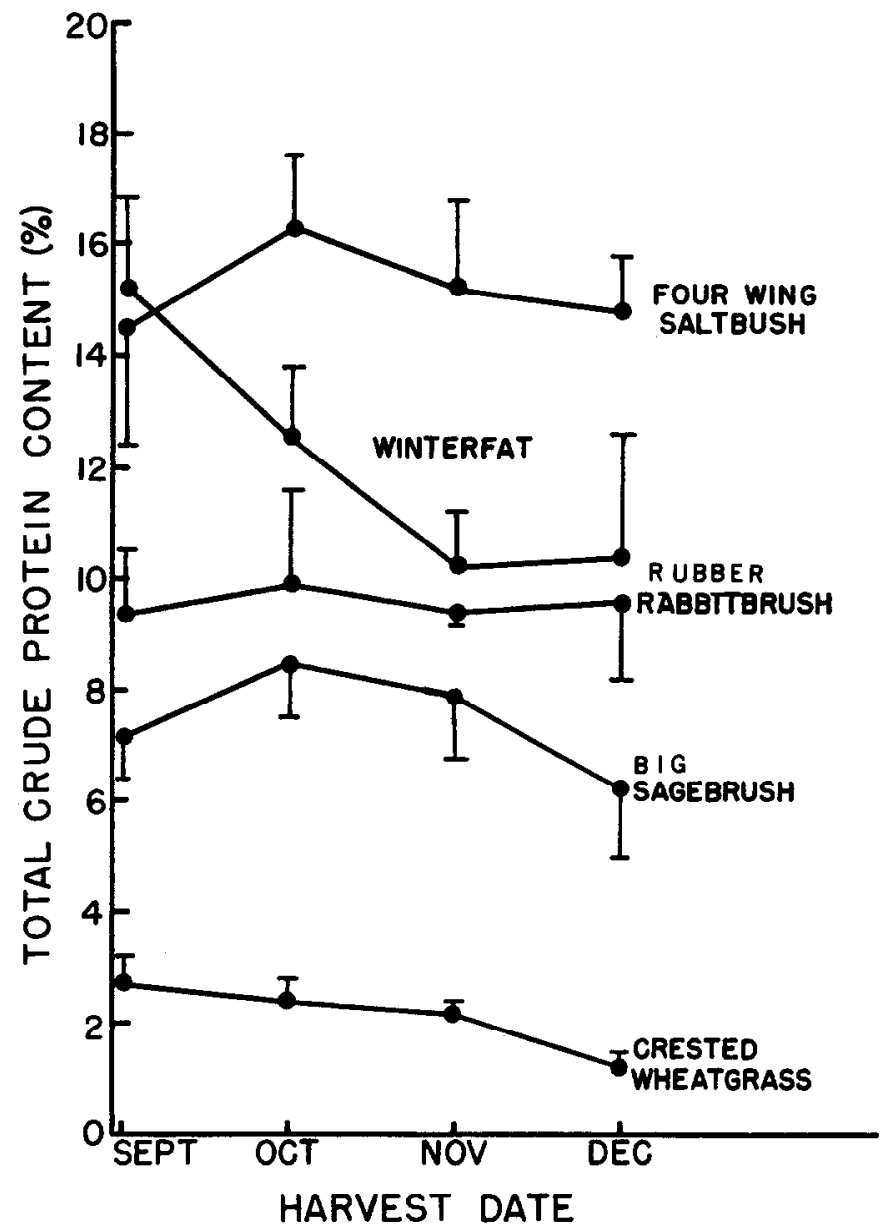

Fig. 1. Changes in average crude protein content (\%) of browse and grass from September to December. Vertical lines indicate half of the $95 \%$ confidence interval of the mean.

In a preliminary grazing trial, 10 sheep were used to determine the effects of pure crested wheatgrass and a mixture of fourwing saltbush and crested wheatgrass on the liveweights after a 20-day grazing period. All animals were weighed before and after the trial. Observations on the grazing behavior in the 2 pastures were recorded.

It should be noted that the approach used in this study does not include all nutrients or effects of feed palatability and other factors that influence forage intake.

\section{Results and Discussion}

\section{Production}

Average annual production for the 4 shrub species sampled was $136.9,213.0,258.5$, and 471.9 grams per plant for mature rabbitbrush, big sagebrush, winterfat, and fourwing saltbush plants, respectively. A similar high productivity of shrubs was also reported by Dietz (1972), who noted that $92 \mathrm{~kg} /$ ha of grazeable browse were produced in the fall by 6 shrub species on a deer range in the black hills of South Dakota. About $73 \%$ of the forage available to sheep during the winter season was from shrubs on Central Utah desert rangelands (Cook et al. 1954).

Post-cure average production of crested wheatgrass was found to be $128.8 \mathrm{~g} / \mathrm{m}^{2}(1,288 \mathrm{~kg} / \mathrm{ha})$. Because of the dormancy of the plants at this time, a high proportion of the herbage may be grazed without severe damage to the plants although some consideration must be given to having a plant residue to serve as a protection against soil erosion.

\section{Nutrient Content}

The total crude protein of shrubs was higher than crested wheat-

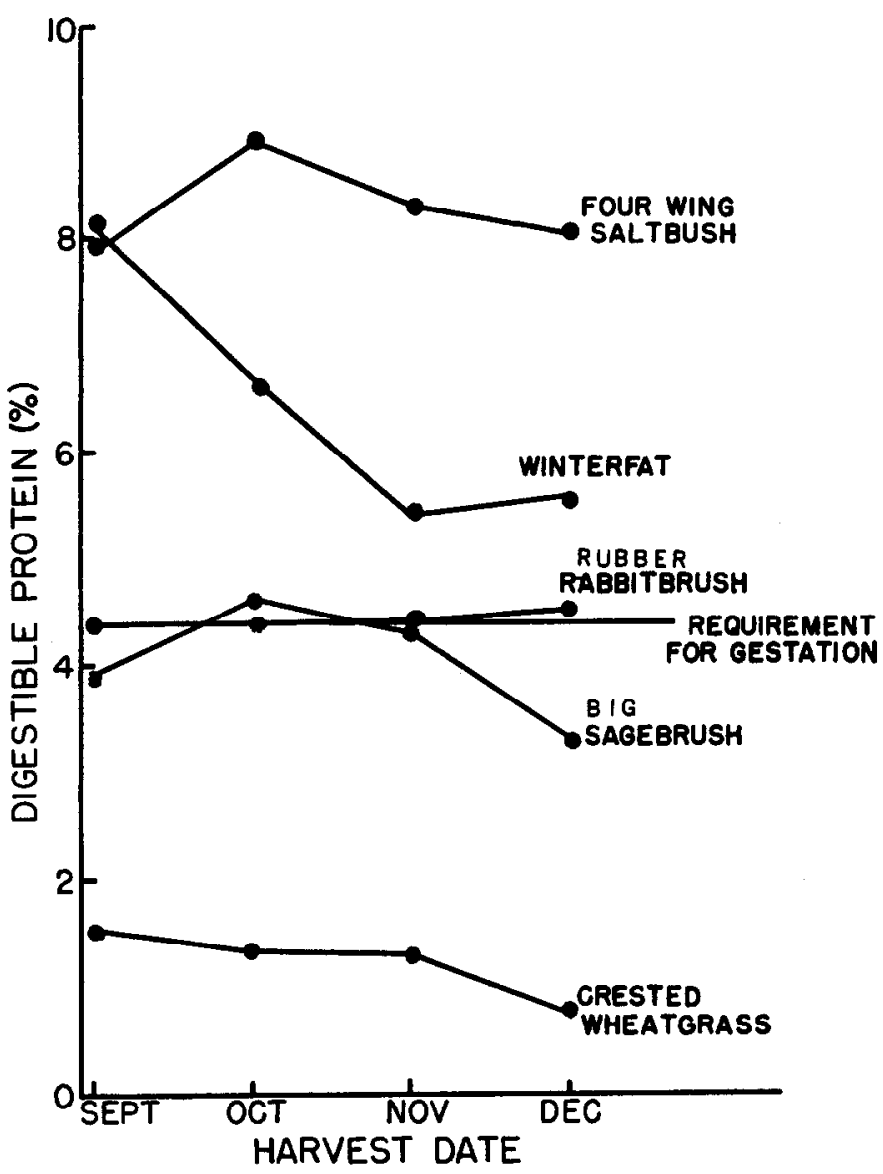

Fig. 2. Calculated digestible protein content of browse and grass species in relation to the nutrient requirements for sheep under range conditions during the gestation period.

grass at each of the harvest dates. Of all shrubs studied, fourwing saltbush had the highest crude protein content (Fig. 1). Although there were significant decreases in the crude protein content from September to December in all species except rabbitbrush, shrubs maintained an adequate protein content to meet the requirements of gestating ewes (Cook and Harris 1968, Cook 1972). In contrast, the crude protein content of crested wheatgrass decreased from $2.7 \%$ in September to $1.2 \%$ in December, much lower than most shrubs during the same period. The low protein content of crested wheatgrass at maturity observed in this study is similar to results reported by Sims et al. (1971). Malechek and Leinweber (1972) also noted a more consistent protein content in deep-rooted shrub species than in grasses and forbs in Texas.

Digestible protein values were calculated from the total crude protein data using digestibility coefficients obtained from Cook and Harris (1968).

Only fourwing saltbush winterfat exceeded digestible protein requirements of gestating sheep (Fig. 2). Rubber rabbitbrush and big sagebrush were very close to the digestible protein requirement for gestating sheep. Digestible protein appears to be the best single factor available to evaluate the nutricnt quality of range forage (Cook et al. 1977). They noted that when the requirements for digestible protein are met by range forage for gestation and lactation, the requirements for energy, phosphorous, and carotene are usually met. This situation holds true only when the range vegetation includes adequate mixes of both browse and grass.

Metabolizable energy values for all plant species were obtained from the literature (Cook and Harris 1968). Crested wheatgrass, like many other grasses, was found to be higher in metabolizable energy content than any of the shrubs studied (Table 1).

Fourwing saltbush and winterfat appear to have a higher desirability than big sagebrush or rubber rabbitbrush as nutritional 
Table 1. A verage D.P. and M.E. contents of shrubs and grass compared to the minimum requirements for gestation.

\begin{tabular}{lcc}
\hline \hline & \multicolumn{2}{c}{ Dry matter basis } \\
\cline { 2 - 3 } & $\begin{array}{c}\mathrm{M} \mathrm{E} \mathrm{E}^{2} \\
\mathrm{Mcal} / \mathrm{kg}\end{array}$ \\
Requirement (60 kg ewe, gestation) & 4.40 & 1.46 \\
\hline Test species & & \\
Rubber rabbitbrush & 4.43 & 1.67 \\
Big sagebrush & 4.04 & 1.27 \\
Winterfat & 6.31 & 1.40 \\
Fourwing saltbush & 8.24 & 1.42 \\
Crested wheatgrass & 1.23 & 1.87 \\
\hline
\end{tabular}

D.P. represents "Digestible Protein."

2ME represents "Metabolizable Energy" (Cook et al. 1968).

supplements to be interplanted with crested wheatgrass for sheep grazing during the dormant season (McKell 1975, McKell and Malechek 1978, Cook and Harris 1968).

Results of simple diet calculations using each shrub species alone plus crested wheatgrass indicated that sheep will require a minimum of $56 \%$ fourwing saltbush, $69 \%$ winterfat, and $99 \%$ rubber rabbitbrush in the diet to meet the minimum requirements for protein and energy (Fig. 3). These calculations were based onthe assumption that the shrubs are palatable and readily utilized by sheep in the mix pastures. Big sagebrush would be unsuitable due to its digestible protein values being lower than required by gestating ewes. In general, sheep diets on winter ranges in Utah contained about $70 \%$ browse and $30 \%$ grass (Cook and Harris 1968). The amounts of shrubs in the diet may be influenced by factors such as palatability and availability.

It was evident during the preliminary grazing trial that sheep readily browsed on fourwing saltbush as soon as they were int roduced into the pasture. The relative preference indices of the various shrubs to sheep will be established in a subsequent trial. The calculated rubber rabbitbrush proportions needed seem unrealistic to implement due to the generally low palatability of rabbitbrush to sheep (Cook 1962).

In a preliminary grazing trial to determine the performance of sheep on pure crested wheatgrass and a mixture of fourwing saltbush and crested wheatgrass in the fall of 1979 , sheep lost about $5 \%$ of their body weight on the pure grass pasture as compared with only $1 \%$ loss on the mix grass-shrub pasture during a 20 -day grazing period.

\section{Literature Cited}

Bleak, A.T., and A.P. Plummer. 1954. Grazing crested wheatgrass by sheep. J. Range Manage. 7:63-68.

Chatterton, N.J., J.R. Goodin, C.M. Mc Kell, R.V. Parker, and J.M. Rible. 1971. Monthly variation in the chemical composition of desert saltbush. J. Range Manage. 24:55-56.

Cook, C.W. 1972. Comparative nutritive values of forbs, grasses and shrubs. p 303-310. In: C.M. McKell, P.J. Blaisdell, and P.R. Goodin (eds). Wildland Shrubs. Their Biology and Utilization USDA Forest Serv. Gen Tech. Rep. INT-1.

Cook, C.W. 1962. An evaluation of some common factors affecting utilization of desert range species. J. Range Manage. 15:333-339.

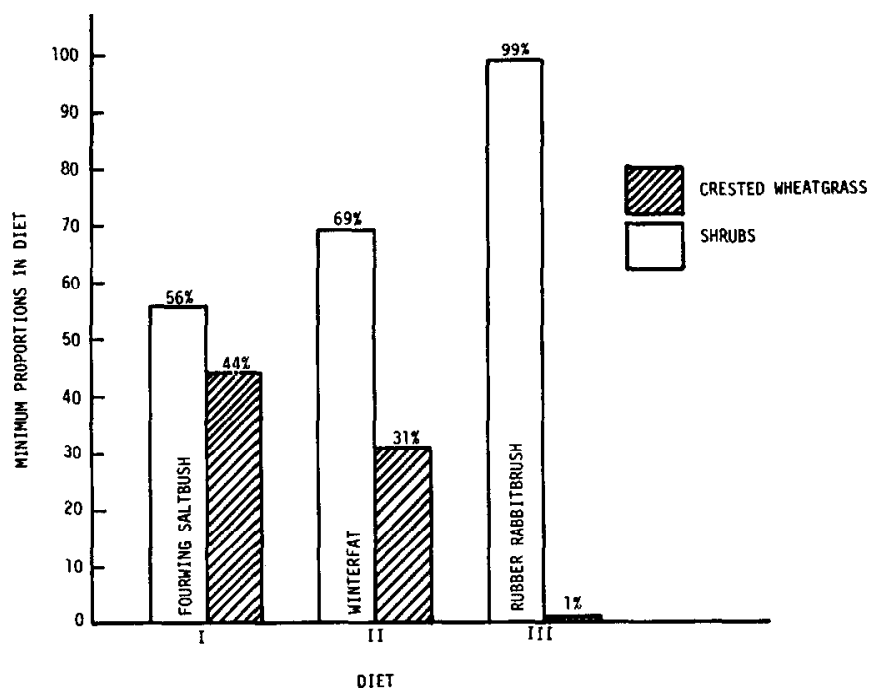

Fig. 3. Required proportions of crested wheatgrass and shrubs in the diet to meet protein and energy requirements of sheep for fall and early winter grazing.

Cook, C.W., and Harris, L.E. 1968. Nutritive values of season ranges. Utah Agr. Exp. Sta., Utah State Univ., Bull. 472. 55 p.

Cook, C.W., L.A. Stoddart, and L.E. Harris. 1954. The nutritive value of winter range plants in the Great Basin as determined with digestion trial with sheep. Utah Agr. Exp. Sta. Bull. 37255 p.

Cook, C.W., R.D. Child, and L.L. Larson. 1977. Digestible proteins in range forages as an index to nutrient content and animal response Colorado State Univ., Range Sci. Dep. Ser. No. 26. 65 p.

Dietz, R.D. 1972. Nutritive value of shrubs. p 289-302. In: C.M. McKell, J.P. Blaisdell, and J.R. Goodin (eds). Wildland Shrubs-Their Biology and Utilization. USDA Forest Serv. Gen, Tech. Rep. INT-1.

Frischknecht, N.C. 1968. Grazing intensities and systems on crested wheatgrass in Central Utah: Response of vegetation and cattle. USDA Forest Serv. Tech. Bull. No. 1388.47 p.

Harris, L.E. 1970. Nutrition research techniques for domestic and wild animals. Vol. I. $501 \mathrm{p}$.

Kearl, L.C., N.C. Frischknecht, and L.E. Harris. 1971. Wheatgrass, native grass and forage grazed by cattle. Proc. Western Soc. of Animal Sci. 22.

Malechek, J.C., and C.L. Leinweber. 1972. Chemical composition and invitro digestibility of forage consumed by goats on highly and heavily stocked ranges. J. Range Manage. 35:1014-1019.

McKell, C.M. 1975. Shrubs-a neglected resource of arid lands. Science 187:803-809.

McKell, C.M., and J.C. Malechek. 1978. The role of shrubs in the management of natural grazing lands with particular reference to protein production. Proc. 8th World-Forestry Congress, Jakarta, Indonesia.

National Reseach Council. 1975. Nutrient requirements of domestic animals. Nutrient requirements of sheep. Fifth edition. 1975. Subcommittee on sheep nutrition, Board of Agr. and renewable Res. and Nat. Res. Council.

Rauzi, F. 1975. Seasonal yield and chemical composition of crested wheatgrass in southeastern Wyoming. J. Range Manage. 28:219-221.

Sims, P.L., A.R. Lovell, and D.F. Harvey. 1971. Seasonal trends in herbage and nutrient production of important sandhill grasses. J. Range Manage. 24:55-59.

Steel, A.D.R., and Jeff Torrie. 1960. Principles and procedures of statistics, with special reference to the biological sciences. McGraw-Hill Book Company, Inc. $481 \mathrm{p}$.

Van Epps, G., A.P. Plummer, and C.M. McKell. 1971. The future potential of shrubs on Utah ranges. Utah Sci. 32:21-23. 